\title{
The Development and Validation of a Module on Enhancing Students' Critical Thinking, Collaboration and Writing Skills
}

\author{
Moustafa Mohamed Abdelmohsen \\ Oman College of Health Sciences, South Sharqiya Branch, Oman
}

\begin{abstract}
This study aims to develop and test the validity of a module on enhancing students' collaboration, critical thinking (2Cs) and writing skills. To develop the module, the researcher used ADDIE model which incorporates five primary phases, namely Analysis, Design, Development, Implementation and Evaluation. The study used a tryout group which incorporated 20 participants who studied English at The General Foundation Program at a private college in Oman. The study employed a pretest-posttest quasiexperimental design. Paired Samples t-Test was used to compare the mean scores of both tests. Apropos of module validity, a total of 5 experts validated the module. The findings revealed that there is a statistically significant mean difference between the participants' scores in both the pretest and posttest. Further, it was found that the module has good validity and reliability.
\end{abstract}

Key words - Module/Instructional Design (ID), critical thinking, collaboration, validity, development.

\section{Introduction}

The conventional curriculum aimed its attention at the teacher rather than the learner.

DOI: $10.18421 /$ SAR34-04

https://doi.org/10.18421/SAR34-04

Corresponding author: Moustafa Mohamed
Abdelmohsen,
Oman College of Health Sciences, South Sharqiya Branch,
Oman.
Email: mustafa0723@yahoo.com

Received: 09 September 2020.

Revised: 05 December 2020.

Accepted: 12 December 2020.

Published: 30 December 2020.

(c) BY-NC-ND (C) 2020 Moustafa Mohamed Abdelmohsen; published by UIKTEN. This work is licensed under the Creative Commons Attribution-NonCommercial-NoDerivs 3.0 License.

The article is published with Open Access at www.sarjournal.com
Nonetheless, recently there has been a paradigm shift that moves the focus from teaching to learning and student-centeredness, therefore, has been furthered. The emphasis is now on how students learn and the effectual learning environment design. Instructional designers are thwarted in their attempt to design effective instructional materials. One of the challenging tasks Instructional designers encounter is delineating efficacious plan with opportune learning outcomes. What are students supposed to know, and what are they supposed to demonstrate at the end of a lesson? Initially, students are in dire need of exhaustive syllabus delineating and expounding the pivotal skills, notions, procedures, theories and concept of the course. Additionally, many students need some of the rudimentary learning tools crucial to achieve the course goals. Hence, assisting students to learn how to learn has become a pivotal component of a sterling course design. This mirrors the dire need for Instructional Design. Instructional Design (ID) is a methodical procedure in which training and educational programs are composed and developed aiming at a considerable enhancement [39].

Instructional Design is the application of systematically formulating, evolving and delivering instructional experiences and products, both physical and digital, in a reliable and consistent fashion towards an inspiring, engaging, effective, appealing and efficient acquisition of knowledge [34],[35]. The process incorporates pinpointing the learners' state and needs, expounding the end goal of instruction, and generating some "intervention" to assist in the transition [15]. Instructional Design is the very heart of effectual learning and teaching. Unless teachers plan, and shape teaching tasks, coincidental learning will be the outcome, and thus the teacher might fail to carry out the evaluation of what has been achieved in classroom [40]. Thus, Instructional Design model remains of substantial significance to both curriculum designers and teachers. There are numerous varied ID models, and many of these models depend on the basic ID "ADDIE" model. This model employs a linear 
process for designing, where each stage is engaged one at a time, and each stage is connected to the earlier phase [33]. The module development in this study is guided by the ADDIE model. ADDIE saves time and it also encourages effective learning. Most importantly, the model helps assure that learners achieve the module or program objectives giving room for the evaluation of learners' needs as well as the efficacy of the module using processes with certain outcomes that can be gauged. The present study aims to develop and validate a module to hone students' collaboration, critical thinking and writing skills. It targets Omani students who learn English at The General Foundation Program in Sur Nursing Institute which functions under the auspices of Omani Ministry of Health. A prototype was used to test the reliability of the module. The prototype was given to a tryout group of 20 Omani students who study English at The General Foundation program at one of the private colleges in Oman. A total of 5 experts validated the module.

\section{Statement of the Problem}

Writing in the General Foundation Program in Oman is deemed one of the salient skills students are required to master to enhance their academic success and personal development. This is because students are required to demonstrate satisfactory writing skills during their coursework and formative and summative assessment. Learning to master writing for the foundation students can enable them to meet their academic requirements and perform competently in their disciplines and professional context [2]. Despite the effort which has been made by teachers to help the Foundation Program students improve their writing ability, they commit innumerable errors in their writing production. The improvement of students' writing is very lackadaisical, slow and distressing which negatively affects their academic performance and language proficiency [37]. The foundation program students encounter tremendous difficulties developing clear and deep-in-depth paragraphs in terms of content, unity, organization, fluency and accuracy [19].

Since language mirrors thinking [9],[10] writing does not only necessitate mastery of linguistic elements such as punctuation, grammar, and vocabulary but also necessitates notional judgment and critical thinking [26], [27]. The foundation students lack in basic critical skills. They are unable to differentiate between opinions and facts or give strong reasons for their opinions [34],[3]. According to Emilia [18], writing requires students to think critically about their choices of words, paragraphs organization, cohesion and clarity and the purpose and topic of writing. Although critical thinking is a skill that is developed via practice, the current writing syllabus does not help the Foundation Program students to think critically about the writing activities or to analyze and evaluate information. Moreover, it does not encourage students to think independently or brainstorm the writing activity to generate ideas and think critically. Consequently, the foundation program students' writing lacks in cohesion and clarity, purpose and topic of writing [4].

One of the most substantial $21^{\text {st }}$ century writing skills that should be embedded in efficacious and successful writing materials are collaboration skills. The plurality of studies and research have pinpointed the advantageous outcomes of writing to learn and learning to write collaboratively [43]. Collaborative writing enables students to mimic and learn from their classmates' writing [12] and also promotes critical reflection [30]. Though collaborative writing is very significant in honing students' writing skills, the writing syllabus, however, does not promote students' collaboration skills [5]. The writing syllabus focuses utterly on individual writing production. Students write on their own without interacting or collaborating with other classmates [1]. The non-existence of collaboration in the writing syllabus does not stimulate the Foundation Program students to work in groups or pairs to construct and develop different ideas for the writing tasks [24]. Hence, there is dire need to develop a module that addresses students' writing, critical thinking and collaboration problems.

\section{Literature Review}

As a realm, instructional design is traditionally and historically rooted in behavioral and cognitive psychology, albeit constructivism has recently impacted thinking in the realm [15],[16] [32]. Instructional design underwent a transition over the last few decades. It has shifted from a focus on knowledge acquisition and skills development to an emphasis on personal construction meaning and users' experience. While "programed instruction", established on behaviorism theories, governed the 1950s and 1960s, modern ID now is more fluid, contextual and student experience driven [39]. During the 1990s, there were many developments that had pivotal influences on the instructional design practices and principals. One of the salient determinants that affected ID during 1990s was the burgeoning interest in constructivism which gathered momentum during the decade. The instructional concepts associated with constructivism incorporate necessitating learners to solve realistic and complex problems; collaborate to solve those problems; study 
the problems from various perspectives; take ownership of the process of learning and become cognizant of their own role in the process of knowledge construction [14]. Rapid prototyping is deemed one of the trends that has recently impacted on instruction design practices. This process encompasses quickly developing and designing a prototype product in the initial phases of an instructional design product and then undergoing a number of rapid tryout and revision phases until a satisfactory version is produced [23]. This design approach has been supported as a method of producing caliber instructional materials in a short time compared to conventional instructional design method [29]. For this reason, this type of product has been adopted for this research. There are several models used for developing instructional design. The most common three models are Bachward Design, Kemp model and ADDIE model. The literature review elaborates on ADDIE model since it was adopted by this study. ADDIE is iterative in comparing and revising of the instructional throughout the process of instructional design. This recursive and recurrent nature is what [6] named 'the input-process-output paradigm'. The structure enables the instructional designers to encompass feedback throughout the process.

\section{Methodology}

\section{Participants}

The tryout group who participated in the pilot test are 20 Omani students who study English at The General Foundation Program at a private college in Oman. The participants' L1 is Arabic. They are secondary school leavers aged between 18 and 19 years old. The participants' level of English is elementary. The tryout group involved 4 males and 16 females.

\section{Research Design}

The current study adopted a mixed-method approach or multi-methodology. Mixed method approach incorporates collecting, analyzing and integrating both qualitative and quantitative data in one single study or research [13]. There are some valid grounds in justification of fostering a mixedmethod approach by the present study. Mixed method approach counteracts the limitations of qualitative or quantitative research [28] and gives more evidence for examining a research problem than either qualitative or quantitative research alone [8]. The researcher made use of a pretest-posttest quasi-experimental approach [17].

\section{Research Instruments Pre-test and Posttest}

To gauge students' writing skills before and after delivery of the prototype, a pre-test and posttest were administered. The pre-test and posttest were an essay writing in which students were asked to write a 250 word argumentative essay on "The impact of technology on our social values." The time allotted for the test was 40 minutes. The researcher used IELTS Academic Writing Task 2 rubrics to asses students' writing ability such as: task achievement, cohesion and coherence, lexical resource and grammatical range and accuracy. Each criterion was assigned a band score between 1.0 and 9.0. The band was calculated as follows:

\section{$\frac{\text { Student's total score }}{4}=$ band score between 1.0-9.0}

\section{Illinois Critical Thinking Essay Scoring Rubric}

To test students' critical thinking skills in both the pre-test and posttest, the researcher made use of Illinois Critical Thinking Essay scoring rubric [21]. This is a standardized test which gauges students' critical thinking skills in argumentative essays. The rubric encompasses six criteria: Focus, Supporting Reasons, Reasoning, Organization, Integration, and Conventions. While the first five criteria are germane to critical thinking, conventions, which is the last criterion, aims attention at gauging students' language proficiency such as paragraph format, punctuation, sentence construction, word usage and spelling. Consequently, the last criterion was excluded as incorporating a facet of language in a critical thinking test that would give invalid assessment about students' critical thinking abilities. Each of the five criterion were rated on a six-point scale (total scores can range anywhere from 6 to 30 points). The scores were interpreted as follows:

1-3 illustrates that the criterion is absent or in the "developing" stages.

4-6 signals that the criterion is basically or welldeveloped.

\section{Reflective Journal Method}

The reflective journal method was used in the current study as a personal record of students' learning experiences. It was the place where the students reflected upon and recorded their observations, feedback and responses to various learning situations embedded in the prototype. The students were given reflective journal forms and were requested to write about their learning experiences, challenges and insights during and after accomplishing every chapter of the prototype. Further, reflective journals gave the students the 
opportunity to record their collaboration experiences in the prototype. To analyze reflective journals qualitative data, [36] method of phenomenological analysis (PA) was employed. The purpose of this method was to elucidate the meaning, essence and structure of the students' experiences pertaining to the prototype. The first step of the analysis, which is called 'Horizontalization', is to meticulously read through the students' reflective journals repeatedly in order to discern or pinpoint pivotal statements in the data and categorize them into groups. After that, each statement is given equal value. Textural categorization is linked to these statements or themes. Hence, the analysis of the participants' reflective journals is informed by intuition or insight and reflection which is based upon thorough and constant reading of the collected data.

\section{Module Development Process}

The present study is guided by ADDIE model of instruction as expounded in the work of [22] who elucidate how the model steps should be implemented

and furnish various tasks that have to be taken into account in each step of the cycle. styles and language needs/wants [7]. The "processoriented' approach has been selected for the present study because it deals with the 'how' of leaning process and attempts to examine the effect of determinants such as students' learning styles which influence second language learning [7]. A needs analysis questionnaire was adapted for the purpose of exploring students' learning needs, writing experience and learning preferences. The questionnaire consists of 3 sections of a total of 45 items. The first section aims to obtain data about the participants' demographic data. Section two incorporates open-ended items which identify students' writing experience and problems such as planning or pre-writing, the writing process, grammar and punctuation. The items are accompanied with a five-point, Likert-type rating scale, ranging from 'very difficult' to 'very easy'. The completed questionnaires were then analyzed via SPSS program. The needs analysis results are as follows:

\section{- Students' demographic data}

There are 20 students aged between 18 and 19 years

old. The group incorporates 4 males $(11.43 \%)$

and 16 females $(88.57 \%)$.

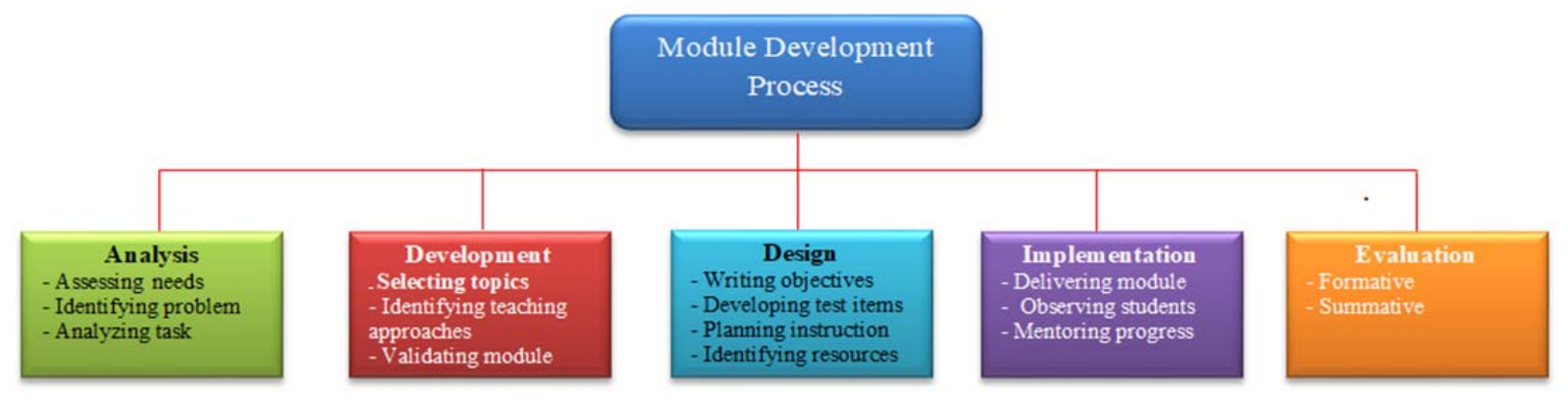

Figure 1. Module Development Process

The term 'ADDIE' is a prevalent reminiscent for the five rudimentary stages in the 'Instructional Design' approach: Analysis, Design, Development, Implementation and Evaluation.

\subsection{Analysis}

In the analysis stage, the instructional problem was clarified, the instructional objectives and goals were established and the students' environment, existing knowledge, and skills were discerned. In this phase, the researcher gathered information about the students' needs, knowledge, critical thinking and writing skills. A needs analysis was conducted as the initial stage of the module design. The needs analysis was based on 'process-oriented' approach which explored students' humanistic needs or the subjective needs incorporating students' preferred learning

\section{- Write up}

The needs analysis results revealed that the students had difficulties in the overall writing process. For instance, the plurality of students encountered difficulties with using vocabulary (86.1\%), editing (94.5\%), paraphrasing (97.2\%), spelling $(94.5 \%)$ and writing a summary $(100 \%)$.

\section{- Planning}

With regard to planning a writing activity, the majority of students' responses ranged from very difficult and difficult. Students faced difficulties in generating $(83 \%)$, organizing $(89 \%)$ and linking ideas $(70 \%)$. This pinpoints that students encounter many difficulties with planning writing activities.

\section{- Grammar}

The students' responses to the grammar items disclosed that they had problems with some grammatical structures such as the use of transitions, 
tenses, prepositions and articles which are 100\%, $88.57 \%, 60 \%$ and $94.29 \%$ respectively.

\section{- Punctuation}

The students' responses for the punctuation items denoted that they had background knowledge about some of the punctuation forms such as the use of periods and question marks. However, students had difficulties with using commas, semicolons, quotation marks and apostrophes.

- Students' learning needs and preferred learning styles

The needs analysis results illustrated that students favored certain writing topics to be incorporated in the module such as descriptive, narrative, causeeffect, process analysis and opinion paragraphs. Accordingly, these had been included in the module. Additionally, it was found that the students preferred some types of learning styles such as active learning style and group preferences. Active learners enjoy doing tasks directly by applying and discussing them with others. Group learners prefer to work in pairs and groups [20]. Moreover, the majority of students $(85.7 \%)$ were not in support of some writing activities such as pictorial stories, writing puzzles and jigsaws. On the contrary, all students (100\%) preferred to see model paragraphs before they embark on writing tasks. Further, the needs analysis results showed that

most of the students $(91.9 \%)$ preferred to receive feedback from classmates on their writing production. All in all, the needs analysis significantly helped the researcher to learn about students' writing problems, background knowledge, writing needs and preferred learning styles.

\subsection{Design}

In the design stage, the researcher created an overall blueprint of how the module would be delivered. The module learning objectives were determined on the basis of the Ministry of Health writing guidelines and participants' needs analysis results. The module was designed to enhance the Foundation Program students' collaboration, critical thinking and writing skills. This module assumed an elementary to pre-intermediate level of L2 writing. Figure 2, below displays what the students will be able to do upon successful completion of the module.

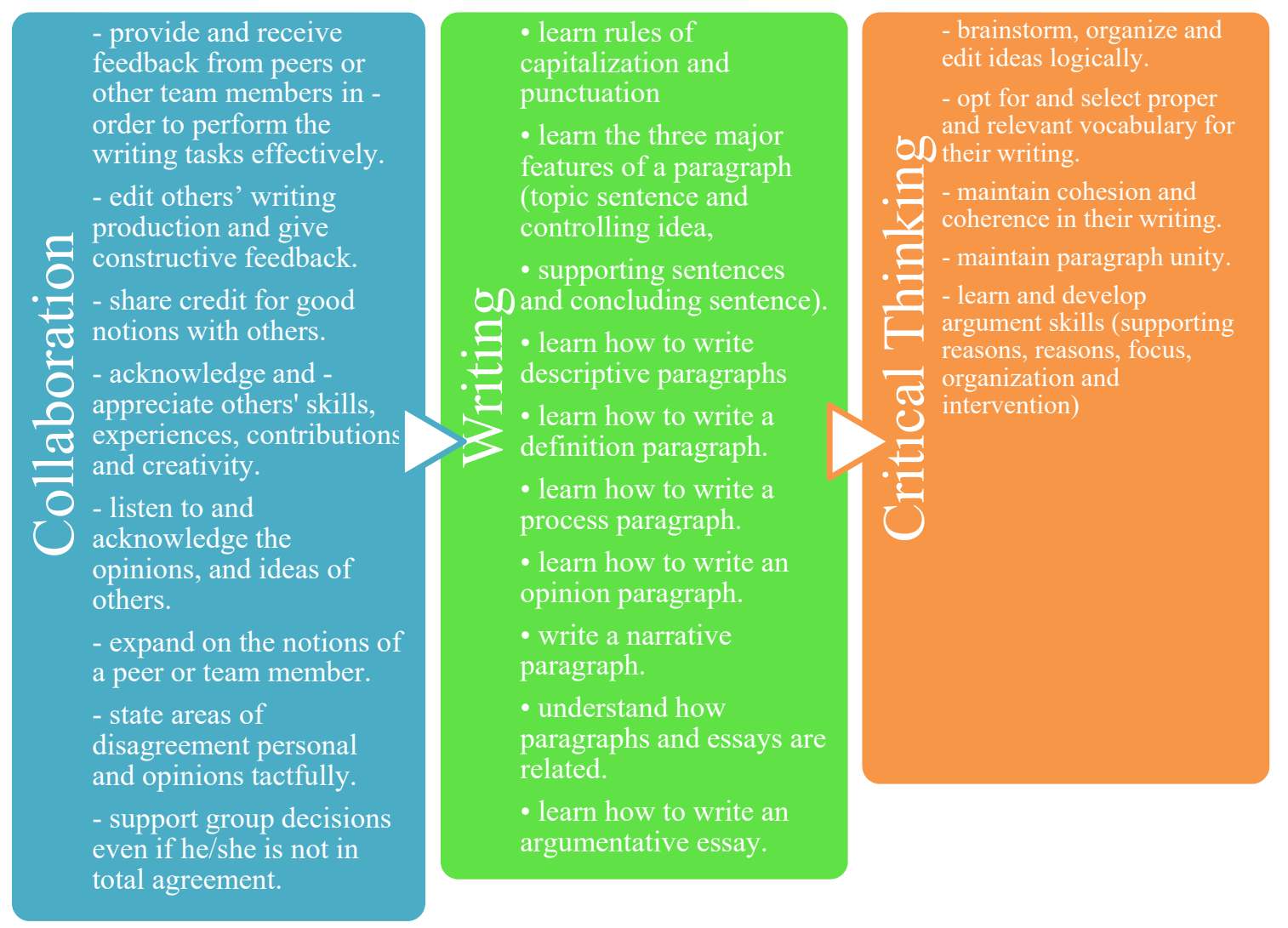

Figure 2. Module learning outcomes 


\subsection{Development}

The development phase incorporates creating and organizing the module. The module was designed to teach to students' needs and adhere to Omani Ministry of Health writing objectives. Consequently, the content of the module was rigorously selected and organized. The module entails 11 chapters. Each chapter has its objectives which conform to the general objectives of the module. The Table below exhibits the module chapters and objectives.

\section{Table 1. Module chapters and objectives}

\begin{tabular}{|c|c|c|c|}
\hline \multicolumn{4}{|c|}{ Module Objectives } \\
\hline $\begin{array}{c}\text { Chapter } \\
1 \\
\end{array}$ & $\begin{array}{l}\text { - To learn how to organize information } \\
\text { into groups. } \\
\text { - To learn how to organize different } \\
\text { elements within a group. } \\
\text { - To identify irrelevant information in a } \\
\text { group of sentences. } \\
\text { - To learn rules of capitalization and } \\
\text { punctuation }\end{array}$ & $\begin{array}{c}\text { Chapter } \\
6 \\
\end{array}$ & $\begin{array}{l}\text { - To learn how to write an opinion } \\
\text { paragraph. } \\
\text { - To identify facts and opinions. } \\
\text { - To use signal words to organize ideas }\end{array}$ \\
\hline \begin{tabular}{|c|} 
Chapter \\
2 \\
\end{tabular} & $\begin{array}{l}\text { - To learn the three major features of a } \\
\text { paragraph (topic sentence and controlling } \\
\text { idea, supporting sentences and } \\
\text { concluding sentence). } \\
\text { - To learn how to write compound } \\
\text { sentences } \\
\text { - To use present simple tense in a } \\
\text { paragraph } \\
\text { - To learn subject-verb-agreement }\end{array}$ & $\begin{array}{c}\text { Chapter } \\
7 \\
\end{array}$ & $\begin{array}{l}\text { - To write a narrative paragraph. } \\
\text { - To organize events in a chronological } \\
\text { order. } \\
\text { - To use connecting words for narration. } \\
\text { - To use simple past tense in a narrative } \\
\text { paragraph }\end{array}$ \\
\hline \begin{tabular}{|c|} 
Chapter \\
$\mathbf{3}$
\end{tabular} & $\begin{array}{l}\text { - To learn how to write a definition } \\
\text { paragraph. } \\
\text { - To learn simple adjective clause } \\
\text { - To use relative pronouns in definitions }\end{array}$ & $\begin{array}{c}\text { Chapter } \\
8\end{array}$ & $\begin{array}{l}\text { - To learn how to write a cause-effect } \\
\text { paragraph. } \\
\text { - To use transitions in cause-effect writing } \\
\text { - To identify and avoid sentence fragments }\end{array}$ \\
\hline $\begin{array}{c}\text { Chapter } \\
4\end{array}$ & $\begin{array}{l}\text { - To learn descriptive language. } \\
\text { - To learn how to order adjectives. } \\
\text { - To learn how to use sensory words in } \\
\text { descriptive paragraphs. } \\
\text { - To learn how to describe people. } \\
\text { - To learn how to describe things. } \\
\text { - To learn how to describe places. }\end{array}$ & $\begin{array}{c}\text { Chapter } \\
9\end{array}$ & $\begin{array}{l}\text { - To learn how to write supporting sentences. } \\
\text { - To learn different types of supporting } \\
\text { sentences. } \\
\text { - To write supporting details. } \\
\text { - To learn how to give examples }\end{array}$ \\
\hline $\begin{array}{c}\text { Chapter } \\
\mathbf{5}\end{array}$ & $\begin{array}{l}\text { - To learn how to write a process } \\
\text { paragraph. } \\
\text { - To learn how to use transition words } \\
\text { - To organize a paragraph using a } \\
\text { chronological order. }\end{array}$ & $\begin{array}{c}\text { Chapter } \\
10\end{array}$ & $\begin{array}{l}\text { - To understand how paragraphs and essays } \\
\text { are related. } \\
\text { - To understand the basic steps in writing } \\
\text { an essay. } \\
\text { - To practice writing different types of essays }\end{array}$ \\
\hline & & $\begin{array}{c}\text { Chapter } \\
11 \\
\end{array}$ & $\begin{array}{l}\text { - To learn how to write an argumentative } \\
\text { essay. } \\
\text { - To learn language of argumentation. } \\
\text { - To formulate an argument with } \\
\text { counterargument. } \\
\text { - To draw a logical conclusion }\end{array}$ \\
\hline
\end{tabular}


The module aims for a learner-centered approach. That is to say that the module is governed by the learning outcomes which were determined after an exhaustive analysis of the Foundation Program students' needs.

The module was carefully and systematically organized to introduce stimulating and practical writing tasks. The total number of hours allotted for teaching the module is 44 hours. Table 2. displays the module delivery plan.

The module employs some teaching approaches which aim to enhance students' writing, critical thinking and collaboration skills.

\section{a.The genre approach}

[31] defines the genre approach as a communication process that incorporates an oriented goal for its members in a specific event of communication which is based on a certain social context. The Foundation Program students will be required to study and analyze a written text and then they will need to provide a writing production akin to the text they have studied. The writing process in the study module incorporates three stages as suggested by [11].

- Modeling: the students will be provided with model texts and they will be required to write their own texts which are similar to the provided ones.

- Construction: the students in this stage will work out the new text construction according to the information obtained from the model text.

- Independent Construction: students in this stage will be expected to produce their own writing making use of the information obtained from the model text.

\section{$b$. The collaborative approach}

To enhance students' collaboration skills, the module provides miscellaneous writing activities which demand students to interact with their peers in order to accomplish the tasks. The plurality of writing tasks will necessitate students to work in pairs or small groups to produce well-formed written texts [25]. Further, the developed module will provide opportunities for self-evaluation through providing the needed metalanguage and by incorporating writing tasks which stimulate students to gauge their own writing achievement.
Table 2. Module delivery plan

\begin{tabular}{|c|c|c|c|}
\hline Chapter & Topic & $\begin{array}{l}\text { Number } \\
\text { of Hours }\end{array}$ & Week \\
\hline 1 & $\begin{array}{l}\text { Getting Started: } \\
\text { Elements of Good } \\
\text { Writing }\end{array}$ & 4 & 1 \\
\hline 2 & Paragraph Writing & 4 & 2 \\
\hline 3 & $\begin{array}{l}\text { Definition } \\
\text { Paragraphs }\end{array}$ & 4 & 3 \\
\hline 4 & $\begin{array}{l}\text { Descriptive } \\
\text { Paragraphs }\end{array}$ & 4 & 4 \\
\hline 5 & $\begin{array}{l}\text { Process Analysis } \\
\text { Paragraphs }\end{array}$ & 4 & 5 \\
\hline 6 & Opinion Paragraphs & 4 & 6 \\
\hline 7 & Narrative Paragraphs & 4 & 7 \\
\hline 8 & $\begin{array}{l}\text { Cause-effect } \\
\text { Paragraphs }\end{array}$ & 4 & 8 \\
\hline 9 & $\begin{array}{l}\text { Supporting the Main } \\
\text { Idea in a Paragraph }\end{array}$ & 4 & 9 \\
\hline 10 & Essay Writing & 4 & 10 \\
\hline 11 & $\begin{array}{l}\text { Argumentative Essay } \\
\text { Writing }\end{array}$ & 4 & 11 \\
\hline & & $\begin{array}{c}\text { Total: } 44 \\
\text { Hours }\end{array}$ & \\
\hline
\end{tabular}

Additionally, the module provides opportunities for peer-evaluation. Peer-evaluation or peer-editing enhances students' writing skills as they will be able to explicitly or implicitly comment on their peers' writing production so they will be able to reinforce their own writing skills and contribute to developing other students' writing skills as well.

\section{c. The infusion approach of critical thinking}

To enhance students' critical thinking skills, the module employs the infusion approach [42]. The approach presumes that students learn a subject along with explicit critical thinking standards. Specifically, the students will be encouraged to think critically within the writing tasks they will be studying. In this module, students will learn to think critically about their choices of words, paragraphs organization and unity, cohesion and clarity and the purpose and topic of writing. Further, the module will develop students' critical thinking skills via argumentative essay writing. An argumentative essay is a kind of essay which introduces arguments about two sides of an issue, argument and counterargument. The module also incorporates a $\mathrm{CD}$ which provides supplementary writing tasks. 


\subsection{Selection of Module Topics}

The selection of the module writing topics conforms with the Ministry of Health syllabus guidelines. The ministry syllabus aims to improve students' writing skills to prepare them for their study disciplines. Further, the writing topics of the developed module were meticulously selected on the basis of their appropriateness and relevance to the students' needs to assure optimal personal engagement and to motivate students to drip further into the module. The developed module has been contextualized to the students' learning needs, realities and experiences and linked to the students' culture and language level. The module incorporates miscellaneous writing topics which are germane to Omani culture, heritage, customs and tradition and local and social celebrations. In addition, the developed module has been contextualized to the writing topics which provide purposeful, meaningful use of the language.

\subsection{Module Validity}

According to [41], module development encompasses module validation by experts and testing its reliability. The researcher used content validity to measure the validity of the module. The module was evaluated by 5 experts who are qualified and with appropriate expertise in module development. A checklist was adapted to test the validity of the module. The developed checklist consists of 36 items of five-point Likert scale from 1 (strongly disagree) and 5 (strongly agree). The researcher made a few modifications to the original checklist so as to better align it with the purpose of the study. To calculate the content validity of module, the research used CVI (content validity index) as proposed by [381. The content validity index is of inter-rater concurrence that is generally utilized as an approach to calculate the concurrence proportion. Content validity index can be calculated via calculating the experts' concurrence on the item (I-CVI) through indicating irrelevant item as 0 . and relevant item as 1 . 1381 maintain that the value of (ICVI) has to be at least .78 or more to highlight good and sufficient validity when more than three experts are included. The overall content validity for scale is S-CVI and the researcher used .80 as the lower acceptability limit for S-CVI.

The table below illustrates the I-CVI and S-CVI/average to gauge experts' consensus on the module.

Table 3. Module I-CVI and S-CVI/average

\begin{tabular}{|c|c|c|c|c|c|c|}
\hline Criteria & Items & Relevant & $\begin{array}{c}\text { Not } \\
\text { Relevant }\end{array}$ & I-CVIs & Interpretation & \\
\hline \multirow{4}{*}{$\begin{array}{l}\text { Module } \\
\text { Objectives }\end{array}$} & 1.The objectives are clearly stated. & 5 & 0 & 1.00 & Excellent & \\
\hline & $\begin{array}{l}\text { 2. The objectives are well-planned, formulated and } \\
\text { organized. }\end{array}$ & 5 & 0 & 1.00 & Excellent & \\
\hline & $\begin{array}{l}\text { 3. The objectives stated are specific, measurable and } \\
\text { attainable. }\end{array}$ & 5 & 0 & 1.00 & Excellent & \\
\hline & $\begin{array}{l}\text { 4.The objectives are relevant to the topics of each chapter } \\
\text { in the book. }\end{array}$ & 5 & 0 & 1.00 & Excellent & \\
\hline \multirow{7}{*}{ Module Content } & 5. The objectives take into account the students' needs. & 5 & 0 & 1.00 & Excellent & \\
\hline & $\begin{array}{l}\text { 6. The content of each chapter is directly relevant to the } \\
\text { defined objectives. }\end{array}$ & 5 & 0 & 1.00 & Excellent & \\
\hline & $\begin{array}{l}\text { 7. The content of each chapter is clear and easy to } \\
\text { understand. }\end{array}$ & 5 & 0 & 1.00 & Excellent & \\
\hline & 8. The topics of chapters are fully discussed. & 5 & 0 & 1.00 & Excellent & \\
\hline & $\begin{array}{l}\text { 9. The topics are supported with illustrative examples, and } \\
\text { the writing activities conform to the level of the students. }\end{array}$ & 5 & 0 & 1.00 & Excellent & \\
\hline & 10. Each topic is given equal emphasis in each chapter. & 5 & 0 & 1.00 & Excellent & \\
\hline & $\begin{array}{l}\text { 11. The CD provides effective and beneficial writing } \\
\text { activities. }\end{array}$ & 5 & 0 & 1.00 & Excellent & \\
\hline \multirow{4}{*}{$\begin{array}{l}\text { Module Format } \\
\text { and Language }\end{array}$} & $\begin{array}{l}\text { 12. The format/layout is well-organized which makes the } \\
\text { chapters interesting. }\end{array}$ & 5 & 0 & 1.00 & Excellent & \\
\hline & 13. The language used is easy to understand. & 5 & 0 & 1.00 & Excellent & \\
\hline & 14. The language used is clear, concise and motivating. & 4 & 1 & .80 & Excellent & \\
\hline & $\begin{array}{l}\text { 15. The instructions in the book are concise and easy to } \\
\text { follow }\end{array}$ & 5 & 0 & 1.00 & Excellent & \\
\hline \multirow{5}{*}{$\begin{array}{c}\text { Module } \\
\text { Presentation }\end{array}$} & 16. The book is systematic in its content presentation. & 5 & 0 & 1.00 & Excellent & \\
\hline & $\begin{array}{l}\text { 17. The chapters of the module are presented in a unique } \\
\text { and original order. }\end{array}$ & 5 & 0 & 1.00 & Excellent & \\
\hline & 18. The writing activities are presented clearly. & 5 & 0 & 1.00 & Excellent & \\
\hline & $\begin{array}{l}\text { 19. The presentation of each chapter is interesting and } \\
\text { attractive to students. }\end{array}$ & 5 & 0 & 1.00 & Excellent & \\
\hline & $\begin{array}{l}\text { 20. Each chapter is provided with sufficient examples and } \\
\text { writing activities. }\end{array}$ & 5 & 0 & 1.00 & Excellent & \\
\hline \multirow{4}{*}{$\begin{array}{l}\text { Module } \\
\text { Usefulness }\end{array}$} & 21. The book is expected to motivate students to write. & 5 & 0 & 1.00 & Excellent & \\
\hline & $\begin{array}{l}\text { 22. The module will help students master the writing topics } \\
\text { at their own pace. }\end{array}$ & 5 & 0 & 1.00 & Excellent & \\
\hline & $\begin{array}{l}\text { 23. The module will allow students to plan the time } \\
\text { allocated for writing more efficiently. }\end{array}$ & 4 & 1 & 0.80 & Excellent & \\
\hline & $\begin{array}{l}\text { 24. The module is expected to develop students' writing, } \\
V_{\text {icritical thinking and collaboration skills. }}\end{array}$ & 5 & 0 & 1.00 & Excellent & 173 \\
\hline
\end{tabular}


There was a general consensus among the five experts about the module content validity. All the five experts concurred that the module has good content validity. The questionnaire items have an ICVI above .80 whereas the S-CVI is .987 which exceeded the minimum I-CVI (.78) and S-CVI (.80) value that was proposed by [38]. To determine the module reliability, the researcher used Cronbach's alpha coefficient. The coefficient obtained was .960 which is deemed very high coefficient of reliability [41].

\subsection{Reliability of the Module}

A pilot test was conducted including 20 students who study English as a foreign language at one of the private colleges in Oman. The pilot test determined the module reliability within the allocated time to pinpoint any problems that may arise during the implementation of the module.

\subsection{Implementation}

After meticulous and rigorous analysis, design and development phases, the module must be delivered or implemented. In the pilot test, the students were given 4 chapters $(2,9,10 \& 11)$ of the module which aim to enhance students' critical thinking, collaboration and writing skills. The students learned 4 chapters for about 4 weeks and for 16 hours. The students' skills were assessed by a number of assignments throughout the module. For instance, the students were given a timed-writing task as an exit activity for each of the 4 chapters.

\subsection{Evaluation}

This phase gauges students' learning progress. Two types of evaluation were carried out: formative evaluation and summative evaluation.

\subsection{Formative Evaluation}

This was an ongoing process which aimed to gauge the development of students' critical thinking, collaboration and writing skills. Initially, the pre-test was administered before giving the prototype to students. The pretest aimed to assess students' critical thinking and writing skills.

\subsection{Summative Evaluation}

This occurs after the implementation of the final version of module. The posttest was administrated to students once they completed 4 chapters of the module. This helped gauge the development of students' critical thinking and writing skills. Table 4 . below exhibits the results of the pretest and posttest.
Table 4. Writing pretest and post test results

\begin{tabular}{cccc}
\multicolumn{4}{c}{ Paired Samples Statistics } \\
\hline Writing Test & Mean & $\begin{array}{c}\text { Standard } \\
\text { Deviation }\end{array}$ & $\boldsymbol{t}$ \\
\hline Pre-test & 8.73 & 0.72 & \\
Posttest & 21.26 & 1.06 & \\
Paired & -1.32 & 3.59 & $\mathbf{- 1 6 . 4 3}$ \\
Samples test & & & \\
\hline
\end{tabular}

The writing pretest scores demonstrate that the tryout group obtained a mean score of (8.73) in the pre-test whereas they scored a mean of (21.32) in the posttest, with significant difference. The means obtained in the two tests signify that there is a significant improvement in the students' writing performance. This indicates that the prototype significantly improved the students' writing skills. With regard to data variability from the point of central tendency, the standard deviation of the pretest $(\mathrm{SD}=0.72)$ and the posttest $(\mathrm{SD}=1.06)$ are fairly big signifying significant difference between the tryout group's performance in both the pre-test and posttests. The paired t-test (-16.43) displays that there is a statistically significant mean difference between the participants' scores in the two tests.

The critical thinking pretest scores exhibited in Table 5. below show that the participants obtained a mean score of (8.35) in the pretest whereas they scored a mean of (21.26) in the posttest, with significant difference. The means obtained entail that the participants' critical thinking skills were significantly enhanced. Specifically, the means of the tryout group illustrate that the level of the use of critical thinking skills in argumentative writing was considerably high in the posttest compared to the pretest. The paired t-test ( $\mathrm{t}$-20.02) demonstrates that there is a statistically significant mean difference between the participants' scores in both the pre-test and posttests.

\section{Table 5. Illinois Critical Thinking pretest and posttest} results

\begin{tabular}{cccc}
\multicolumn{4}{c}{ Paired Samples Statistics } \\
\hline $\begin{array}{c}\text { Critical } \\
\text { Thinking Test }\end{array}$ & Mean & $\begin{array}{c}\text { Standard } \\
\text { Deviation }\end{array}$ & $\boldsymbol{t}$ \\
\hline Pre-test & 8.35 & 2.03 & \\
Posttest & 18.15 & 2.83 & $\mathbf{- 2 0 . 0 2}$ \\
Paired & -1.23 & 2.75 & \\
Samples test & & & \\
\hline
\end{tabular}

In order to examine students' collaboration experience, they were requested to complete reflective journals during the pilot test. The reflective journals provided data about participants' learning experience, challenges, insights and collaboration experience during the field tryout. The majority of students mentioned that they benefited from the 
prototype which helped them to improve their collaboration skills via the various activities embedded in the module. Students stated that they were able to collaboratively brainstorm writing activities, exchange ideas and get and provide feedback on others' writing. Apparently, collaboration enabled students to be active members within their groups. Students stated that they were able to express their opinions freely and openly. In addition, students mentioned that they respected other students' opinions and welcomed their feedback on their writing. The participants encountered some challenges with regard to learning new vocabulary introduced in the model paragraphs. The amount of vocabulary was too much for students to learn so they requested more time to be given to learning the new vocabulary. With regard to collaboration aspects in the module, the participants indicated that working with classmates, whether in pairs or groups, was interesting and useful. Collaborative writing helped the participants to exchange ideas and share meanings of new words. They also mentioned that writing was no longer a frightening or boring experience.

During the field tryout, it was observed that the participants were restless and frequently changed their groups to carry out the writing activities. When they were asked to work in pairs or groups, it was observed that some students tried to dominate the discussions. However, after some time it was observed that students were able to work in harmony. They were able to provide and receive feedback from peers or other team members in order to perform the writing tasks effectively; edit others' writing production and give constructive feedback; share credit for good notions with others; acknowledge and appreciate others' skills, experiences, contributions and creativity; listen to and acknowledge the opinions, and ideas of others; and support group decisions even if he/she is not in total agreement. The students participated actively in pair and group discussions but they were sometimes noisy so they were requested to do the activities quietly. It was also observed that the participants did not have any preferences for working with certain students, such as close friends, but they collaboratively went around the classroom and joined any group of students. In addition, students competed to work out the writing activities fast and be the first to submit their work to the teacher.

\section{Recommended Revision to the Prototype}

Experts' comments in the validity phase suggested no alterations in the module content. Nevertheless, data that has been collected during the tryout proposed few revisions that need to be made to the 4 chapters which were given to students. Students should be given sufficient time to learn the new vocabulary, so they can use them in their writing production. It is suggested to include a minidictionary to provide meaning of words. That will be time-saving and will also help students learn meanings of vocabulary. Further, it was observed that students competed for early submission of their writing. Students need to be informed that early submission of their writing production is desirable, but they should also consider the caliber of their writing.

\section{Conclusion}

This paper provided a comprehensive elucidation of the process of module development and validity. The paper used ADDIE model which incorporates five stages, namely Analysis, Design, Development, Implementation, and Evaluation. Validation of the module was carried out by 5 experts. The validity results demonstrated that the module has good validity. Further, the module had high coefficient of reliability. A pretest and posttest were used to gauge the development of students' critical thinking and writing skills during the tryout. The Sample Paired-t test results showed that the module improved the tryout group's critical thinking and writing skills. Students' reflection journals demonstrated that students' collaboration skills were enhanced as well. The researcher hopes that the elucidation of the design process, incorporating the evaluation methods and results, will prove useful to those who have the interest to develop similar instructional modules. The design and developments facets, when used opportunely, should lead to developing an effectual module that is instructionally well-grounded and sound. 


\section{References}

[1]. Al Ajmi, A., \& Ali, H. I. H. (2014). Collaborative writing in group assignments in an EFL/ESL classroom. English linguistics research, 3(2), 1-17.

[2]. Al Badi, I. A. H. (2015). Academic writing difficulties of ESL learners. In The 2015 WEI international academic conference proceedings (Vol. 1, No. 1, pp. 65-78).

[3]. Al-Kindi, N. S., \& AL-Mekhlafi, A. M. (2017). The Practice and Challenges of Implementing Critical Thinking Skills in Omani Post-Basic EFL Classrooms. English Language Teaching, 10(12), 116-133.

[4]. Al Siyabi, J. (2019). Omani Undergraduate Students', Teachers' and Tutors' Metalinguistic Understanding of Cohesion and Coherence in EFL Academic Writing and their Perspectives of Teaching Cohesion and Coherence.

[5]. Al Tai, Y. (2015). The effect of collaboration on Omani students' writing: a comparison between individual, pair and group work. European Scientific Journal, 1, 145-171.

[6]. Branch, R. M. (2009). Instructional design: The ADDIE approach (Vol. 722). Springer Science \& Business Media.

[7]. Brindley, G. (1989). The role of needs analysis in adult ESL programme design. The second language curriculum, 63, 78.

[8]. Caracelli, V. J., \& Greene, J. C. (1993). Data analysis strategies for mixed-method evaluation designs. Educational evaluation and policy analysis, 15(2), 195-207.

[9]. Chaffee, J. (2014). Thinking critically. Nelson Education.

[10]. Cook, T. D., Campbell, D. T., \& Day, A. (1979). Quasi-experimentation: Design \& analysis issues for field settings (Vol. 351). Boston: Houghton Mifflin.

[11]. Cope, B. A., \& Kalantzis, M. (1993). Background to genre teaching. The powers of literacy: A genre approach to teaching writing. London: Falmer.

[12]. Corcelles, M., \& Castelló, M. (2017). Learning philosophical thinking through collaborative writing in secondary education. Journal of Writing Research, 2015, Vol. 7, Núm. 1.

[13]. Creswell, J. W. (2003). Research design: qualitative, quantitative, and mixed methods approaches (2nd ed.). Sage.

[14]. Driscoll, P.M. (2000). Psychology of Learning for Instruction. Massachusetts.

[15]. Duffy, T. M., \& Cunningham, D. J. (1996). Constructivism: implications for the design and delivery of instruction. In D. Jonassen (Ed.), Handbook of Research for Educational Communications and Technology (pp. 170-198). Simon \& Schuster Macmillan

[16]. Duffy, T. M., \& Jonassen, D. H. (1996). Constructivism: new implications for instructional technology. In T. Duffy \& D. Jonassen (Eds.), Constructivism and the technology of instruction (pp. 1-16). Erlbaum.
[17]. Edmonds, W. A., \& Kennedy, T. D. (2013). An Applied Reference Guide to Research Designs. Sage.

[18]. Emilia, E. (2010). Teaching writing: Developing critical learners. Bandung, Indonesia: Rizqi Press.

[19]. Faller, J. M. V. (2018). Grammarly investigation into EFL writing issues involving Omani learners. International Journal of Language and Linguistics, 5(3), $165-174$.

[20]. Felder, R. M. (1993). Reaching the second tier. Journal of college science teaching, 23(5), 286290.

[21]. Finken, M., \& Ennis, R. H. (1993). Illinois critical thinking essay test. Illinois critical thinking project. Department of Educational Policy Studies University of Illinois.

[22]. Gagne, R. M., Wager, W. W., Golas, K. C., Keller, J. M., \& Russell, J. D. (2005). Principles of instructional design. $\quad$ Performance Improvement, 44(2), 4446.

[23]. Gustafson, K., \& Branch, R. M. (1997). Survey of instructional development models (3rd ed.). ERIC Clearinghouse on Information \& Technology.

[24]. Ginosyan, H., \& Tuzlukova, V. (2015). Enhancing Omani University students' writing and study skills: Discussion forum module. Indonesian Journal of Applied Linguistics, 4(2), 56-67.

[25]. Harsono, Y. M. (2007). Developing Learning Materials for Specific Purposes. TEFLIN, 18(2), 170.

[26]. Heaton, J. B. (1989). Writing English language tests. Longman Pearson Education.

[27]. Hosseini, M., Taghizadeh, M. E., Abedin, M. J. Z., \& Naseri, E. (2013). In the importance of EFL learners' writing skill: Is there any relation between writing skill and content score of English essay test. International Letters of Social and Humanistic Sciences, 6(1), 1-12.

[28]. Jick, T. D. (1979). Mixing qualitative and quantitative methods: Triangulation in action. Administrative science quarterly, 24(4), 602611.

[29]. Jones, T. S., \& Richey, R. C. (2000). Rapid prototyping methodology in action: A developmental study. Educational Technology Research and Development, 48(2), 63-80.

[30]. MacArthur, C., Schwartz, S., Graham, S., Molloy, D., \& Harris, K. R. (1996). Integration of strategy instruction into a whole language classroom: A case study. Learning Disabilities Research \& Practice, 11(3), 168-176.

[31]. Martin, J. R. (1999). Factual writing: Exploring and challenging social reality. Deakin University Press.

[32]. Mayer, R. E. (1992). Cognition and instruction: Their historic meeting within educational psychology. Journal of educational Psychology, 84(4), 405.

[33]. McDonald, J., \& Mayes, T. (2007). The changing role of an instructional designer in the implementation of blended learning at an Australian university. In Instructional design: Case studies in communities of practice (pp. 170-192). IGI Global. 
[34]. Mehta, S., Al-Mahrooqi, R., Denman, C., \& AlAghbari, K. (2018). Assessing omani university entrants' critical thinking skills with the cornell classreasoning test form x. Pertanika Journal of Social Sciences and Humanities, 26(4), 2229-2242.

[35]. Merrill, M. D. (1996). What new paradigm of ISD?. Educational Technology, 36(4), 57-58.

[36]. Moustakas, C. (1994). Phenomenological research methods. Sage publications.

[37]. El Houda, M. S. N. (2016). The Impact of Poor Handwriting on EFL Students Test Scores (Doctoral dissertation, University of Biskra).

[38]. Polit, D. F., Beck, C. T., \& Owen, S. V. (2007). Is the CVI an acceptable indicator of content validity? Appraisal and recommendations. Research in nursing \& health, 30(4), 459-467.
[39]. Reiser, R. \& Dempsey, J.V. (2007). Trends and issues in instructional design and technology. Prentice Hall.

[40]. Seel, N. M., Lehmann, T., Blumschein, P., \& Podolskiy, O. A. (2017). Instructional design for learning: Theoretical foundations. Springer.

[41]. Sidek M. N. \& Jamaluddin A. (2005). Module building: how to build a training module and an academic module. University Putra Malaysia Publisher.

[42]. Swartz, A. (1987). Teaching for thinking: a developmental model for the infusion of thinking skills into mainstream instruction. In J. Baron, \& R. Sternberg (Eds.), Teaching Thinking Skills: Theory and Practice, (pp. 106-126). W. H. Freeman \& Co.

[43]. Yarrow, F., \& Topping, K. J. (2001). Collaborative writing: The effects of metacognitive prompting and structured peer interaction. British journal of educational psychology, 71(2), 261-282. 